висока м'язова маса, що може забезпечувати кращі показники ФЗД у даній групі. При порівнянні поширеності паління встановлено, що курці або колишні курці переважали у групі ХОЗЛ (79\%), при поєднаній патології частота становила $73 \%$ і у групі хворих з БА - 43\%. При проведенні тесту з 6-ти хвилинною ходьбою встановлено, що хворі 3 поєднанням астма-ХОЗЛ мали найнижчу толерантність до фізичного навантаження. Проте у хворих 3 астма-ХОЗЛ та ожирінням показники були на 8,7\% вищими ніж у хворих без ожиріння.
Висновки. Отже, згідно результатів дослідження, для пацієнтів з поєднанням астми та ХОЗЛ характерними $\epsilon$ більш виражена респіраторна симптоматика, а саме задишка та тривалий кашель 3 виділенням мокротиння, нижча толерантність до фізичних навантажень, вищий відсоток жирової, м'язової маси та вісцерального жиру та менш виражена обструкція при проведенні спірометрії в порівнянні із групою ХОЗЛ.

Чернецька Н.В., Федів О.І., Ступницька Г.Я.

\title{
Особливості клінічного перебігу хронічного обструктивного захворювання легень, посднаного із цукровим діабетом типу 2
}

\author{
ВДНЗ України « Буковинський державний медичний університет», м. Чернівці, Україна
}

Відомо, що хронічне обструктивне захворювання легень (ХОЗЛ) характеризується розвитком системного запального процесу, наслідком якого $є$ зростання частоти супутньої патології, зокрема цукрового діабету типу 2 (ЦД типу 2). Доведено, що серед хворих на ХОЗЛ порушення вуглеводного обміну спостерігається частіше i це не тільки пов'язано із застосуванням медикаментів. Останнім часом, активно вивчаються патогенетичні взаємозв'язки поєднаної патології, проте залишаються не до кінця вивченими питання діагностики та лікування.

Отже, актуальним є вивчення особливостей поєднаного перебігу ХОЗЛ із ЦД типу 2.

Мета - вивчити особливості клінічного перебігу, показники функції зовнішнього дихання (ФЗД), біоімпедансометрії, толерантность до фізичного навантаження та індекс BODE у хворих на ХОЗЛ, поєднаного із ЦД типу 2.

Матеріали та методи. Обстежено 20 практично здорових осіб та 80 хворих, які перебували на лікуванні у пульмонологічному відділенні Обласної клінічної лікарні, м. Чернівці. Пацієнти були розділені на дві репрезентативні групи: 28 хворих на ХОЗЛ (перша група) та 30 пацієнтів на ХОЗЛ, поєднаного із ЦД типу 2 (друга група).

Всі пацієнти відповідали критеріям включення та виключення у дослідження та підписали інформовану згоду на дослідження. Діагноз ХОЗЛ та ЦД типу 2 виставляли згідно із міжнародними рекомендаціями. У дослідження були включені пацієнти із GOLD 2 та 3 стадією та В, С групи. Усім пацієнтам проводили спірометрію (спірограф "BTL 08 SpiroPro" (Великобританія), біоімпедансометрію (портативний апарат BC-601 (TANITA, Японія) та тест толерантності до фізичного навантаження (6-хвиллинна ходьба). Індекс
BODE розраховували за IMT, шкалою задишки, ОФВ 1 та 6-хвилинною ходьбою.

Результати. При обстеженні пацієнтів встановлено, що клінічна симтоматика за поєднаного перебігу ХОЗЛ та ЦД типу 2 була більш вираженою (турбував частіше кашель із виділенням харкотиння та мав триваліший перебіг, за шкалою задишки середня кількість балів була вищою ніж при ХОЗЛ на 23,5\%, $(\mathrm{p}<0,05)$, аускультативна картина в легенях мала також більш торпідний характер).

При порівнянні частоти загострень виявлено, що при ХОЗЛ, поєднаного із ЦД типу 2 хворі на $25,8 \%$ $(\mathrm{p}<0,05)$ частіше були госпіталізовані у відділення. При вивченні ФЗД, встановлено, що показники спірометрії мали тенденцію до більш низьких даних за поєднаного перебігу ХОЗЛ та ЦД типу 2. ОФВ 1 був на $12,7 \%(\mathrm{p}<0,05)$ нижчим у другій групі хворих. Такі показники як ФЖЕЛ, ПОШвид, СОШ25-75 також були на $13,4,14,8$ та 23,5\% відповідно нижчими порівняно із першою групою пацієнтів $(\mathrm{p}<0,05)$.

Аналіз показників біоімпедансометрії показав вірогідно вищий IMT (на 21,8\%), відсоток жирової маси (на 23,6\%), рівень вісцерального жиру (на 34,6\%) та меншу м'язову масу (на 17,6\%) за поєднаного перебігу ХОЗЛ та ЦД типу 2.

При вивченні толерантності до фізичного навантаження встановлено, що хворі другої групи проходили меншу відстань за 6 хвилин (на 23,5\%, p<0,05) порівняно із пацієнтами на ХОЗЛ.

Інтегральний індекс BODE, який характеризує тяжкість перебігу ХОЗЛ був за поєднаного перебігу із ЦД типу 2 вірогідно нижчим на $18,7 \%$ порівняно із першою групою. 
Отже, за результатами нашого дослідження встановлено, що для хворих на ХОЗЛ із ЦД типу 2 характерним $\epsilon$ більш торпідний клінічний перебіг (виражений кашель та задишка, аскультативна картина в легенях, вища частота госпіталізацій 3 приводу загострення захворювання). Показники ФЗД $\left(\mathrm{OФB}_{1}\right.$, ФЖЕЛ, ПОШвид, СОШ25-75) були також нижчими у даного контингенту хворих на тлі змін складу тіла (вірогідно вищий IMT, відсоток жирової маси, рівень вісцерального жиру та низької м'язової маси). Відстань, яку хворі на ХОЗЛ із ЦД типу 2 проходили за 6 хвилин, була нижчою порівняно із першою групою пацієнтів.
Інтегральний індекс BODE також був нижчим у першій групі пацієнтів.

Висновки. У хворих на ХОЗЛ із ЦД типу 2 спостерігається тяжчий клінічний перебіг, нижчі показники ФЗД, зміна складу тіла (вищий IMT, відсоток жирової маси, рівень вісцерального жиру та зниження м'язової маси), зниження толерантності до фізичного навантаження. Для даного контингенту хворих $\epsilon$ характерним тяжчий перебіг і відповідно прогноз захворювання порівняно із групою хворих на ХОЗЛ.

Горох B.B.

\section{Оцінка хворими на хвороби крові та кровотворних органів доступності та якості первинної медичної допомоги}

Сумський державний університет, м. Суми, Україна

Мета - дослідити та проаналізувати рівень доступності та якість первинної медичної допомоги для населення Сумської області із хворобами крові та кровотворних органів.

Матеріали та методи. За спеціально розробленою анкетою було опитано 200 жителів області хворих на хвороби крові та кровотворних органів. При виконанні роботи використано соціологічний та медикостатистичний методи. При проведенні дослідження були збережені конфіденційні дані про респондентів.

Результати. Першим кроком дослідження було вивчення частоти звертання опитаних за медичною допомогою до сімейних лікарів. Отримані результати наведено в табл. 1.

Аналіз отриманих даних даних вказує на те, що за медичною допомогою до лікарів загальної практики -

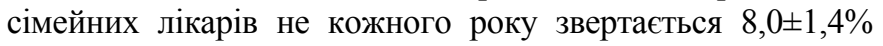
респондентів, $44,0 \pm 2,5 \%$ із них звертається до 5 разів на рік, a $31,5 \pm 2,3 \%$ опитаних звертається більше 5 разів на рік.
Таблиця 1. Частота звертання жителів Сумської області із хворобами крові та кровотворних органів за медичною допомогою до лікаря загальної практики-сімейного лікаря

\begin{tabular}{|l|c|c|}
\hline \multicolumn{1}{|c|}{ Показник } & Абс. & \% \pm \\
\hline Щорічно & 33 & $16,3 \pm 1,8$ \\
\hline Не кожного року & 16 & $8,0 \pm 1,4$ \\
\hline До 5 разів на рік & 88 & $44,0 \pm 2,5$ \\
\hline Більше 5 разів на рік & 63 & $31,5 \pm 2,3$ \\
\hline
\end{tabular}

При цьому в ході дослідження отримані дані, що тільки $52,0 \pm 2,5 \%$ опитаних, які мають хвороби крові та кровотворних органів знаходиться під диспансерним наглядом у лікаря загальної практики-сімейного лікаря.

Далі вивчалося та аналізувалося питання щодо оцінки доступності та якості респондентами первинної медико-санітарної допомоги. Результати дослідження наведено в табл. 2.

Таблиця 2. Оцінка населенням Сумської області із хворобами крові та кровотворних органів доступності та якості первинної медико-санітарної допомоги

\begin{tabular}{|c|c|c|}
\hline Показник & Абс. & $\% \pm$ \\
\hline \multicolumn{3}{|c|}{ Територіальна доступність первинної медичної допомоги } \\
\hline Доступна & 131 & $65,5 \pm 2,4$ \\
\hline Скоріше доступна ніж недоступна & 39 & $19,5 \pm 2,0$ \\
\hline Скоріше недоступна ніж доступна & 26 & $13,0 \pm 1,7$ \\
\hline Недоступна & 4 & $2,0 \pm 0,7$ \\
\hline
\end{tabular}

